\title{
EXPRESSION OF SYNTHETIC PHYTOCHELATIN EC20 IN E. COLI INCREASES ITS BIOSORPTION CAPACITY AND CADMIUM RESISTANCE
}

\author{
EXPRESSÃO DA FITOQUELATINA SINTÉTICA EC2O EM E. COLI AUMENTA SUA \\ CAPACIDADE DE BIOSSORÇÃO E RESISTÊNCIA AO CÁDMIO.
}

\author{
Cleide Barbieri de SOUZA ${ }^{1}$; Elisabete José VICENTE ${ }^{2}$ \\ 1. Doutora Biotecnologia, Laboratório de Genética de Microrganismos, Instituto de Ciências Biomédicas-ICB, Universidade de São \\ Paulo-USP, Cidade Universitária, SP, Brasil. cleidebarbieri@gmail.com; 2. Departamento de Microbiologia, Instituto de Ciências \\ Biomédicas-ICB, Universidade de São Paulo-USP, Cidade Universitária, SP, Brasil.
}

\begin{abstract}
In this study E. coli recombinant clones that express the EC20 synthetic phytochelatin intracellularly were constructed. The increasement of $\mathrm{Cd}^{2+}$ biosorption capacity, and, also, the increasement of resistance to this toxic metal were analyzed. A gene that encodes the synthetic phytochelatin EC20 was synthesized in vitro. The EC2O synthetic gene was amplified by PCR, inserted into the DNA cloning vectors pBluescript ${ }^{\circledR} \mathrm{KS}^{+}$and $\mathrm{pGEM}^{\circledR}$-TEasy, and also into the expression vectors pTE [pET-28(a) ${ }^{\circledR}$ derivative] and pGEX-T4- $2^{\circledR}$. The obtained recombinant plasmids were employed for genetic transformation of E. coli: pBsKSEC20 and pGEM-EC20, they were introduced into DH10B and DH5 $\alpha$ strains, similarly to pTE-EC20 and pGEX-EC20 that were introduced into BL21 strain. The EC20 expression was confirmed by SDS-PAGE analysis. The recombinant clones' resistances to $\mathrm{Cd}^{2+}$ were determined by MIC analyses. The MIC for $\mathrm{Cd}^{2+}$ of DH10B/pBKS-EC20 and DH10B/pGEM-EC20 were $2.5 \mathrm{mM}$ (EC20 induced), and $0.312 \mathrm{mM}$ (EC20 repressed); respectively, 16 and 2 times higher than the control DH10B/pBsKS $(0.156 \mathrm{mM})$. The MIC for $\mathrm{Cd}^{2+}$ of BL21/pTE-EC20 was $10.0 \mathrm{mM}$ (EC20 induced) and $2.5 \mathrm{mM}$ (EC20 repressed), compared with the control BL21/pTE which was only $1.25 \mathrm{mM}$. Analysis of ICP-AES showed that BL21/pGEX-EC20, after growth on the condition of EC20 expression, absorbed $37.5 \%$ of $\mathrm{Cd}^{2+}$, and even when cultured into the non-induction condition of EC20 expression, it absorbed $11.5 \%$. These results allow the conclusion that recombinant $E$. coli clones expressing the synthetic phytochelatin EC20 show increased capacity for $\mathrm{Cd}^{2+}$ biosorption and enhanced resistance to this toxic ion.
\end{abstract}

KEYWORDS: Escherichia coli. Phytochelatin. Biosorption. Bioremediation. Cadmium.

\section{INTRODUCTION}

Recently, industrial and other human activities have been generating environmental pollution in a never observed amounts, creating demands for the development of new remediation techniques. Polluting organic materials can, in most cases, be completely degraded, and that is called bioremediation (GAYLARDE; BELLINASO; MANFIO, 2005; PERELO, 2010). However, metal pollutants tend to persist indefinitely in the environment thus threatening ecosystems as they accumulate along the food chain (AKPOR; MUCHIE, 2010).

The speciation of a metal (different chemical forms/species metal can exist in nature) determines its bioavailability, mobility and destination (REEDER; SCHOONEN; LANZIROTTI, 2006; LADEIRA et al., 2014).

Conventional chemical or physical wastewater treatment are often inappropriate to reduce metal concentrations to the acceptable regulatory standards, and in general, they are cost- expensive and result on hazardous products (AKPOR; MUCHIE, 2010; GIRIPUNJE; FULKE; MESHRAM, 2015).

A promising alternative that grows on demand and development is the use of biomaterials for biosorption of toxic heavy metals. These biomaterials are named as biosorbents (VOLESKY; HOLAN, 1995; GAVRILESCU, 2004; GADD, 2009; WANG; CHEN, 2009; GUPTA; NAYAK; AGARWAL, 2015), they are beginning to be used in bioremediation of metal contaminated waters (GAVRILESCU, 2004; AKPOR; MUCHIE, 2010; AYANGBENRO; BABALOLA, 2017). Compared to traditional physicochemical techniques, bioremediation of toxic metals presents advantages such as lower costs, superior performance and safety, besides being environmentally friendly (GADD, 2009; WANG; CHEN, 2009; GUPTA; NAYAK; AGARWAL, 2015; AYANGBENRO; BABALOLA, 2017).

There are a wide variety of microorganisms (bacteria, fungi, yeasts and algae) that have good potential for use in bioremediation processes as 
Expression of synthetic...

biosorbents for heavy metals (VOLESKY; HOLAN, 1995; WANG; CHEN, 2009; AYANGBENRO; BABALOLA, 2017).

As most heavy metals are cationic, this determinate their sorption into negatively charged functional hydroxides $(-\mathrm{OH})$ or thiol (-SH) groups present on the surfaces of the biosorbents. In the cells, several groups interact with metal species allowing its capture, including cysteine $\mathrm{SH}$ group (GADD, 2009; WANG; CHEN, 2009). All living cells, in the presence of toxic heavy metals, produce cysteine-rich peptides such as glutathione (GSH), phytochelatins (PCs), and metallothioneins (MTs) that bind metal ions (such as $\mathrm{Cd}^{2+}, \mathrm{Cu}^{2+}, \mathrm{Cr}^{3+}, \mathrm{Cr}^{5+}$, $\mathrm{Hg}^{2+}, \mathrm{Mn}^{2}, \mathrm{~Pb}^{2+}$ ), turning them into biologically inactive forms (STILLMAN, 1995; COBBETT; GOLDSBROUGH, 2002).

The best-efficient heavy metal-binding molecules are the phytochelatins (PCs) which are repetitions of the $\gamma$-GluCys dipeptide followed by a terminal Gly [( $\gamma$-GluCys $\left.\left.)_{n}-G l y ; n=2-11\right)\right]$. So, PCs are oligomers of glutathione enzymatically linked by gama-type ligation (MEHRA; MULCHANDANI, $1995 ; \quad$ COBBETT; GOLDSBROUGH, 2002).

Considering the advantage PCs offer as they are short cysteine-rich peptides, Bae et al. (2000) constructed recombinant $E$. coli strains expressing synthetic phytochelatins (ECs; $\alpha$ Glu-Cys)nGly, $n=8$ 20 ) by the normal bacterial transcription ribosomal machinery. These ECs were expressed in fusion with the outer membrane protein A (OmpA) and became linked onto the bacterial cell surface. The resulting recombinants accumulate a substantially higher amount of $\mathrm{Cd}^{2+}$ than the wild-type cells (BAE et al., 2000). After that, genetic engineered bacteria expressing phytochelatin biosynthesis genes (SAUGE-MERLE et al., 2003; WAWRZYŃSKA et al., 2005) or synthetic phytochelatin genes are emerging as new tools for environmental remediation of heavy metals (BAE; MEHRA; MULCHANDANI; 2001; BIONDO et al., 2012; CHATURVEDI; ARCHANA, 2014; YANG et al., 2017).

On this study, the construction of recombinant Escherichia coli strains expressing the synthetic phytochelatin EC20 intracellularly was described, as well as the consequent increases on the capacity of $\mathrm{Cd}^{2+}$ biosorption and the resistance to this toxic ion of these recombinant clones in comparison to the original phenotypes of nontransformed strains.

\section{MATERIAL AND METHODS}

SOUZA, C. B.; VICENTE, E. J.

\section{Bacterial strains and growth conditions}

In this study we used the $E$. coli strains DH5 $\alpha$, DH10B (SAMBROOK; RUSSELL, 2001) and BL21-DE3 $\left(\right.$ Novagen $^{\circledR}$ ). The cell growth was carried out at $37{ }^{\circ} \mathrm{C}$ in liquid Luria Bertani medium - LB and in low-phosphate medium - MJS (UEKI et al, 2003). When required, the mediums were supplemented with $60 \mu \mathrm{g} / \mathrm{mL}$ carbenicillin or 50 $\mu \mathrm{g} / \mathrm{mL}$ kanamycin (SAMBROOK; RUSSELL, 2001). All mediums were elaborated with components and microbiological grade salts supplied, respectively, by Difco $^{\circledR}$ and SigmaAldrich/Merck ${ }^{\circledR}$. Cultures in solid and liquid media were incubated at $37^{\circ} \mathrm{C}$ in incubator chamber and in shaker (180 rpm), respectively.

\section{In vitro construction of the synthetic phytochelatin $E C 20$ codifying gene}

The EC2O synthetic gene was constructed employing the strategy described by Bae et al. (2000) and standard molecular protocols (SAMBROOK; RUSSELL, 2001). Some GAA and TGT codons were changed for GAG and TGC, to prevent unwanted hybridization. The oligonucleotides EC-A: 5'TTTGGATCCATGGAATGTGAATGTGAATGT GAATGTGAATGTGAATGTGAATGTGAGTGT GAATGTGAGTGCGAATGCGAA3' (site BamHI-italicized), and EC-B: 5'TTTAAGCTTTTAACCACATTCACATTCACAT TCACATTCACATTCACATTCGCATTCACATT CGCATTCGCATTCGCACTC $3^{\prime}$ (site HindIIIitalicized) were mixed, boiled, and cooled for hybridization of the bold sequences. The mixture was treated with the Klenow fragment of DNA polymerase enzyme. This double strand was used as template in a PCR reaction with the primers ec-a (5'-tttggatcca-3') and ec-b (5'-tttaagcttt-3'), and the enzyme taq-DNA polymerase, resulting in the DNA fragment BamHI $\rightarrow$ Hind III (EC2O synthetic gene, 141bp) (Figure 1-a). All nucleotides and enzymes were purchased from Promega ${ }^{\circledR}$ and Fermentas ${ }^{\circledR}$, respectively. The thermocycler machine used was "MJ Research-model PTC-200".

\section{Cloning the $E C 20$ synthetic gene}

The EC2O synthetic gene and the plasmid pGEM-TEasy (Promega ${ }^{\circledR}$ ) were mixed with T4DNA ligase, and that ligation mixture (SAMBROOK; RUSSELL, 2001) was used on the genetic transformation of E. coli DH10B strain. Plasmids isolated from some randomly selected recombinant clones were digested with $\mathrm{BamHI}$ and EcoRI (site present in the pGEM-TEasy plasmid) and analyzed in a gel submitted to electrophoresis, 
to select the plasmid pGEM-EC20 (Figure 1-b). For the subsequent plasmids' constructions, the EC2O DNA fragment was obtained by PCR using as template PGEM-EC20, primers T3 and T7 $\left(\right.$ Promega $\left.^{\circledR}\right)$, as well as the enzyme High Fidelity DNA polymerase. The amplicon was digested with BamHI-HindIII (Figure 1-c) and linked to the cloning plasmid pBsKS [pBluescriptKS(+)] $\left(\right.$ Stratagene ${ }^{\circledR}$ ) and to the expression vector pTE [a pET-28(a) - Novagen ${ }^{\circledR}$ derivative without the Histag codifying region: the original plasmid was digested with $\mathrm{NcoI}$ and $\mathrm{BamHI}$, treated with Klenow DNA polymerase, and relinked using DNA T4 ligase], both pre-digested with the same enzymes, using DNA T4 ligase. The PCR EC2O amplicon flanked by BamHI and EcoRI (Figure 1-c) was also linked to vector pGEX-T4-2 (Promega ${ }^{\circledR}$ ) previously digested with the same enzymes, using DNA T4 ligase (Figure 1-d).

The plasmids pGEM-EC20 and pBsKSEC20 were used on the genetic transformations of E. coli $\mathrm{DH} 5 \alpha$ and DH10B strains, respectively. The expression recombinant plasmids pTE-EC20 and pGEX-EC20 were used for genetic transformations of E. coli BL21-DE3 (Merck $\left.{ }^{\circledR}\right)$ strain. This resulted into recombinant clones DH5 //pGEM-EC20, DH10/pBsKS-EC20, BL21/pTE-EC20 and BL21/pGEX-EC20.

\section{DNA sequencing}

For DNA sequencing, we used $\mathrm{T} 3$ and $\mathrm{T} 7$ $\left(\right.$ Promega $^{\circledR}$ ) primers, BigDye ${ }^{\circledR}$ sequencing-Kit, sequencing machine "ABI 3730 DNA Analyzer", and the software "Sequencing Analysis 5.3.1 with the Base Caller KB" from Applied Biosystems ${ }^{\circledR}$.

\section{Protein expression methods}

The recombinant clones BL21/pTE-EC20 and BL21/pGEX-EC20 were cultured in LB medium+IPTG (final concentration $800 \mu \mathrm{M}$ ), at 37 ${ }^{\circ} \mathrm{C}$, in shaker (180 rpm), until Abs600nm 1.0. The total amount of protein was extracted and analyzed by SDS-PAGE. Since EC20 protein has only $4.6 \mathrm{kDa}$, $17.5 \%$ acrylamide was used (LAEMMLI, 1970; SAMBROOK; RUSSELL, 2001).

\section{Heavy Metals Resistance Determination}

Analytical-grade $\mathrm{CdCl}_{2} .2 .5 \mathrm{H}_{2} \mathrm{O} \quad\left(\right.$ Merck $\left.^{\circledR}\right)$ was used to prepare $0.1 \mathrm{M}$ stock solution and was sterilized by membrane filtration $(0.22 \mu \mathrm{m}$, Millipore $^{\circledR}$ ). Deionized water was used throughout the study. Recombinant clones were pre-cultured in $3.0 \mathrm{~mL}$ of LB medium plus antibiotic, incubated at $200 \mathrm{rpm}$, at $37{ }^{\circ} \mathrm{C}$, for 24 hours. For EC20 expression induction it was added $2 \mathrm{mM}$ IPTG (final concentration $800 \mu \mathrm{M}$ ), and for its repression it was added 2\% glucose (SAMBROOK; RUSSELL, 2001). From those pre-cultures, $25 \mu \mathrm{L}$ was inoculated into $25 \mathrm{~mL}$ of fresh liquid MJS medium with the same supplement additions. Each one of those cultures were distributed in 10 tubes: $4.0 \mathrm{~mL}$ were poured into the first tube and $2.0 \mathrm{~mL}$ in the remaining tubes. To the first tube it was added $\mathrm{CdCl}_{2}$ to a final concentration of $10 \mathrm{mM}$, and from that, $2.0 \mathrm{~mL}$ were transferred to the next tube, successively. The tubes were incubated at $37{ }^{\circ} \mathrm{C}$, $200 \mathrm{rpm}$, for 24 hours. The minimal inhibitory concentration (MIC) of $\mathrm{Cd}^{2+}$ for the clones was determined by visual observation of the turbidity (ANDREWS, 2001). All experiments were performed in duplicates.

\section{Heavy Metals Bioaccumulation}

In duplicates, recombinant clones were cultured in $5.0 \mathrm{~mL}$ of $\mathrm{LB}$ medium plus antibiotic and incubated at $37{ }^{\circ} \mathrm{C}, 200 \mathrm{rpm}$, for 16 hours. 30 $\mu \mathrm{L}$ were inoculated in $30 \mathrm{~mL}$ of fresh medium with the same composition. The initial cell concentration was standardized at $\mathrm{Abs}_{600 \mathrm{~nm}}$ 0.15. After 1-hour incubation, IPTG (final concentration $800 \mu \mathrm{M}$ ) was added for the EC20 expression induction. The cultures were incubated until $\mathrm{Abs}_{600 \mathrm{~nm}} 0.5$. The cells were harvested by centrifugation $\left(4^{\circ} \mathrm{C}, 6000 \mathrm{~g}, 20\right.$ min). The pellet cells were suspended in $50 \mathrm{~mL}$ $\mathrm{CdCl}_{2} 1.000 \mu \mathrm{M}$, incubated at $37^{\circ} \mathrm{C}, 200 \mathrm{rpm}$, for 2 hours, and centrifuged $\left(4^{\circ} \mathrm{C}, 6.000 \mathrm{~g}, 20 \mathrm{~min}\right)$. The remaining $\mathrm{Cd}^{2+}$ in the supernatant was determined by Inductively Coupled Plasma Atomic Emission Spectrometry - ICP-AES (ESPECTRO ${ }^{\circledR}$-ARCOS), the calibration curve was made with a $1000 \mathrm{ppm}$ cadmium mono-element standard solution.

\section{RESULTS}

The DNA fragment codifying EC20 synthetic phytochelatin was constructed in vitro and amplified by PCR (Figure 1-a). The EC2O synthetic gene was inserted into two cloning plasmids pGEMTEasy $\left(\right.$ Promega $^{\circledR}$ ) and pBluescriptKS(+) $\left(\right.$ Stratagene $\left.{ }^{\circledR}\right)$ resulting in the recombinant plasmids pGEM-EC20 (Figure 1-b) and pBsKS-EC20 (Figure 1-c). These recombinant plasmids were used in the genetic transformation of E. coli $\mathrm{DH} 10 \mathrm{~B}$ and DH5 $\alpha$ strains. EC2O (Figure 1-c) was also inserted into the expression vectors pTE (a pET-28(a)Novagen ${ }^{\circledR}$ derivative constructed in this research) and pGEX-T4-2-(Promega ${ }^{\circledR}$ ) (Figure 1-d) resulting in the recombinant plasmids pTE-EC20 and pGEXEC20. 


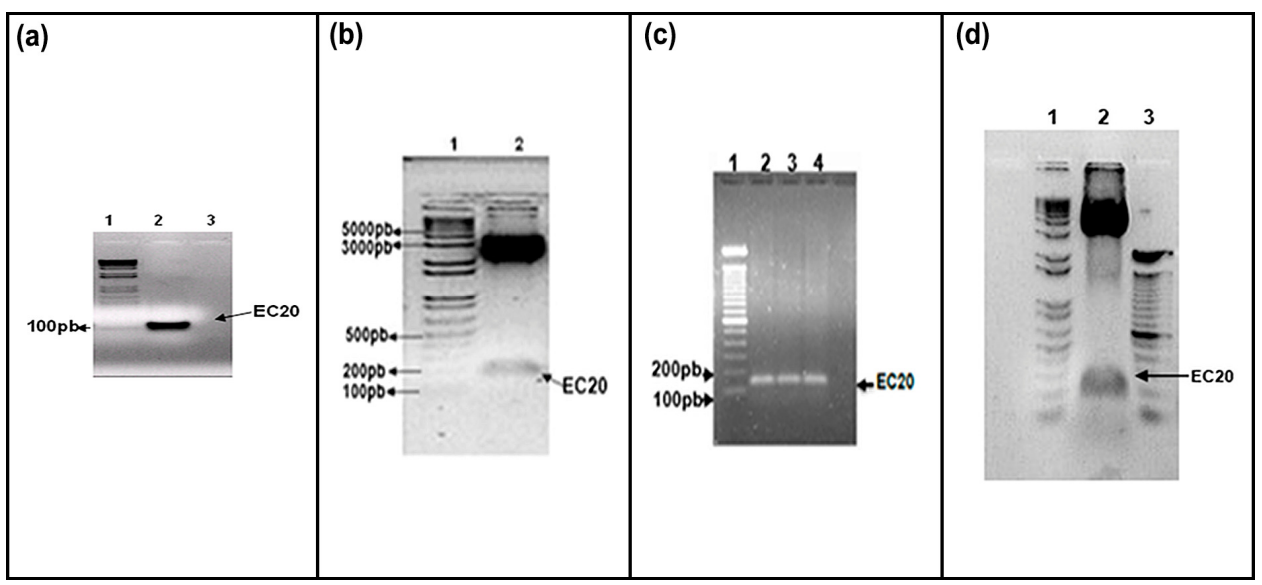

Figure 1. Migration profiles of DNA fragments on 1.0\% agarose gels after electrophoresis and subsequent staining with $0.02 \%$ ethidium bromide: (a) 1-Molecular marker $100 \mathrm{pb}\left(\right.$ Invitrogen $\left.^{\circledR}\right), 0.8 \mu \mathrm{g}$; 2DNA fragment synthetic phytochelatin EC20 after PCR amplification. (b) 1- Molecular marker $1 \mathrm{~kb}$ (Invitrogen $\left.{ }^{\circledR}\right), 0.8 \mu \mathrm{g}$; 2-PGEM-EC20 digested with BamHI and EcoRI. (c) 1- Molecular marker 100 $\mathrm{pb}$ (Invitrogen $\left.{ }^{\circledR}\right), 0.8 \mu \mathrm{g}$; 2- Amplicon obtained by PCR (EC2O synthetic gene) using as template the plasmid PGEM-EC20 and the primers T3 and T7 (Promega $\left.{ }^{\circledR}\right) ; 3-E C 20$ synthetic gene amplicon digested with BamHI and HindIII; 4- EC2O synthetic gene amplicon digested with BamHI and EcoRI. (d) 1- Molecular marker $1 \mathrm{~kb}$ (Invitrogen ${ }^{\circledR}$ ), $0.8 \mu \mathrm{g}$; 2- pGEX-EC20 digested with BamHI and EcoRI; 3- Molecular Marker 100 bp DNA (Invitrogen ${ }^{\circledR}$ ), $0.8 \mu \mathrm{g}$.

The synthetic phytochelatin EC20 expression was analyzed by SDS-PAGE. The clones BL21/pTE-EC20 expressed a $4.6 \mathrm{kDa}$ protein, the corresponding expected weight for the EC20 protein

(data not show). The clone BL21/pGEX-EC20 expressed a protein band with $30.6 \mathrm{kDa}$ corresponding to the fusion protein EC20-GST (4.6 $\mathrm{kDa} / \mathrm{EC} 20$ plus $26 \mathrm{kDa} / \mathrm{GST}$ ) (Figure 2-b).

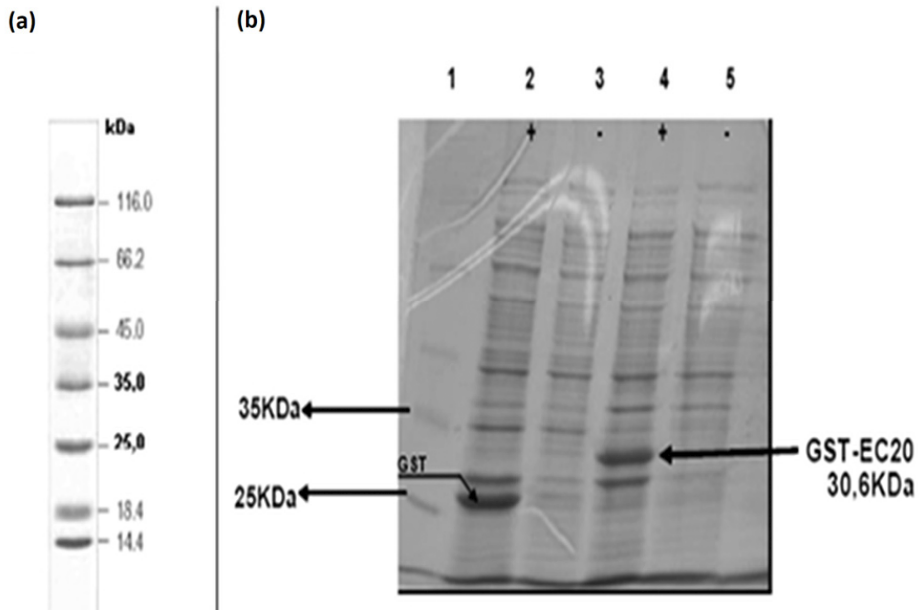

Figure 2. Expression analysis of the fusion protein EC20-GST by SDS-PAGE (17.5\% acrylamide): (a) Protein molecular weight standard SM043 (Fermentas ${ }^{\circledR}$ ). (b) 1- Molecular weight standard SM0431 protein $\left(\right.$ Fermentas $\left.^{\circledR}\right) ; 2$ and 3- total proteins expressed by the negative control BL21(DE3)/pGEX-4T-2; 4 and 5- total proteins expressed by the recombinant clone BL21/pGEX-EC20: $(2,4)$ after growth in the induction condition of EC20 expression $(2.0 \mathrm{mM}$ IPTG) and $(3,5)$ of EC20 repression expression (with glucose).

The E. coli recombinant clones resistance (or tolerance) to heavy metal were analyzed by determination of the MIC (minimum inhibitory concentration) of $\mathrm{Cd}^{2+}$ for the clones. The MICs of
$\mathrm{Cd}^{2+}$ for the recombinant clones came from E. coli DH5 $\alpha$ or DH10B strains harboring the plasmids pGEM-EC20 (data not show) or pBsKS-EC20, the results were $2.5 \mathrm{mM}$ and $0.312 \mathrm{mM}$ after cells 
growth, respectively, under the inducing and the repressing condition of EC20 expression, compared to $0.156 \mathrm{mM}$ for the corresponding untransformed E. coli strains that do not express the EC20 protein (negative controls) (Figure 3-a).

The $\mathrm{Cd}^{2+}$ MICs for the recombinant clones derived from E. coli BL31 harboring the plasmid
SOUZA, C. B.; VICENTE, E. J.

pTE-EC20 or pGEX-EC20 were $10 \mathrm{mM}$ and 2.5 $\mathrm{mM}$ after growing the cells, respectively, under condition of induction and repression of EC20 expression; compared with $1.25 \mathrm{mM}$ for the E. coli BL31 strain which does not express the EC20 protein (negative control) (Figure 3-b).

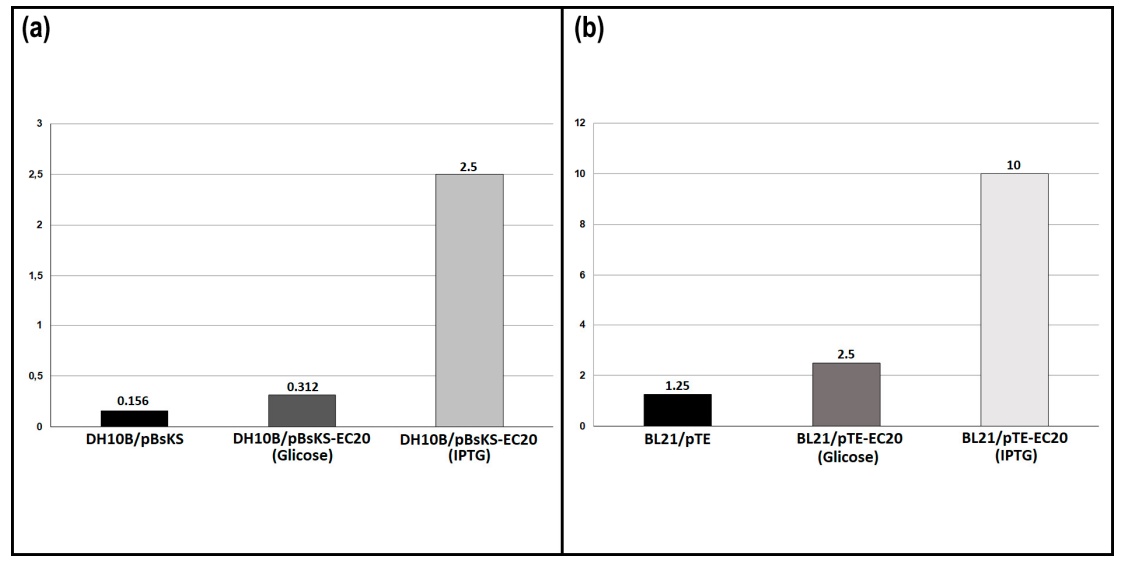

Figure 3. $\mathrm{MIC}$ of $\mathrm{Cd}^{2+}$ showed by the E. coli recombinant clones.

The cells were grown in MJS liquid medium supplemented with $\mathrm{CdCl}_{2}, 37^{\circ} \mathrm{C}$, with agitation in shaker: (a) Recombinant clones: DH10B/pBsKS (negative controls without EC20), DH10B/pBsKS-EC20 cultured with glucose (repressed condition of EC20 expression), DH10B/pBsKS-EC20 cultured with IPTG (induction condition of EC20 expression). (b) Recombinant clones: BL21/pTE (negative controls without EC20), BL21/pTE-EC20 cultured with glucose (repressed condition for EC20 expression), BL21/pTE-EC20 cultured with IPTG (induction condition for EC20 expression).

The heavy metal biosorption capacity of the recombinant E. coli clones were settled. Cells from the bacterial recombinant clones were incubated in aqueous solution of $\mathrm{Cd}^{2+}$ and, after removing the cells from the solutions, the amount of remaining $\mathrm{Cd}^{2+}$ was quantified by ICP-AES (Inductively Coupled Plasma - Atomic Emission Spectroscopy).
The Recombinant clone BL21/pGEX-EC20 cells, after growth in the EC20 protein expression repression condition, absorbed $11.5 \%$ of the total amount of $\mathrm{Cd}^{2+}$ present in water; and these cells, after growth in the induction condition of the EC20 expression, absorbed $37.5 \%$ of the total amount of $\mathrm{Cd}^{2+}$ present in water (Figure 4).

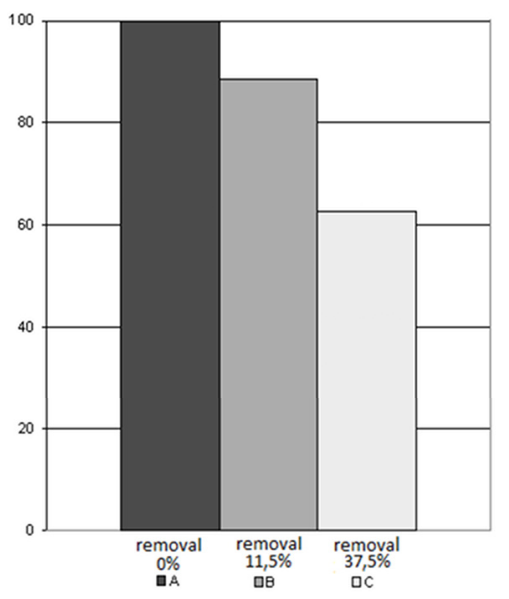

Figure 4. Absorption capacity of $\mathrm{Cd}^{2+}$ from E. coli recombinant clones.

A $1.000 \mu \mathrm{M} \mathrm{CdCl}_{2}$ water solution was incubated with bacterial cells. After the treatment, the total amount of $\mathrm{Cd}^{2+} \mathrm{was}^{2}$ determined by ICP ICP-AES. A- Untreated solution and B- treated solution with: BL21/pGEX-EC20 clone cells grown on glucose-medium (repressed condition for EC20 expression); and C- treated solution with: BL21/pGEX-EC20 clone cells grown on medium supplemented with IPTG (induced condition for EC20 expression). 


\section{DISCUSSION}

In this study, the construction of recombinant $E$. coli clones expressing the EC20 synthetic phytochelatin was demonstrated, consequently, we could notice the clones increasement in their capacities for $\mathrm{Cd}^{2+}$ biosorption and resistance to this toxic ion.

To accomplish that, a double-stranded synthetic DNA fragment encoding for the EC20 synthetic phytochelatin (EC20 gene) was constructed in vitro (Figure 1-a), amplified by PCR,inserted into the cloning plasmids (pBluescript ${ }^{\circledR} \mathrm{KS}^{+}$and $\mathrm{pGEM}^{\circledR}$-TEasy) and into the expression plasmids pET-28a $(+)^{\circledR} \quad$ [derivative without His-tag constructed in this work] and pGEX-4T-2 ${ }^{\circledR}$.

The molecular constructions (pGEM-EC20, pBsKS-EC20, pTE-EC20 and pGEX-EC20) were confirmed by restriction analysis, amplification by PCR (Figure 1-b, c, d) and DNA sequencing. The recombinant plasmids pGEM-EC20, pBsKS-EC20 were inserted into $E$. coli $\mathrm{DH} 5 \alpha$ and $\mathrm{DH} 10 \mathrm{~B}$ strains. The recombinant plasmids pTE-EC20 and pGEXEC20 were inserted into E. coli BL21-DE3 strain, as it offers valuable benefits of maximal expression of a cloned gene.

As expected, the recombinant clone BL21/pGEX-EC20, after growth in the inducing condition of EC2O expression, produced a $30.6 \mathrm{kDa}$ recombinant protein corresponding to a fusion of glutathione-S-transferase (GST, $26 \mathrm{kDa}$ ) and EC20 synthetic phytochelatin $(4.6 \mathrm{kDa})$, as shown in SDSPAGE analysis (Figure 2-b).

We were able to observe that the expression of EC20 also grants a great increasement on the resistance to $\mathrm{Cd}^{2+}$ of the recombinant clones. Clones harboring plasmids pBsKS-EC20 or pGEM-EC20, after growth in the condition of EC2O expression induction, became 16 times more resistant to $\mathrm{Cd}^{2+}$, and even after growth in the condition of EC2O repressed expression, they remain 8 times more resistant to $\mathrm{Cd}^{2+}$ in comparison with the original untransformed strains (Figure 3-a). The clones $E$. coli BL21 harboring the plasmid pTE-EC20 or pGEX-EC20 (BL21/pTE-EC20 and BL21/pGEXEC20), after growth in the condition of induction and repression, EC2O expression showed, respectively, MICs to $\mathrm{Cd}^{2+} 8$ and 2 times higher than the MIC of the original BL21 strain (without EC20) (Figure 3-b). The observed increasement on resistance to $\mathrm{Cd}^{2+}$ showed by the clones expressing
SOUZA, C. B.; VICENTE, E. J.

EC20 is particularly relevant because it is a desired and valuable phenotype for a bacterium that must perform bioaccumulation of toxic heavy metal as a strategy for environmental bioremediation.

As far as we know, the only previous study describing increasement to metal resistance resulting from EC20 expression was seen in $D$. radiodurans, and in that case, the 2.5 -fold increasement was considered an amazing result (CHATURVEDI; ARCHANA, 2014).

The ICP-AES analysis was used to quantify the remaining amount of $\mathrm{Cd}^{2+}$ present in water after treatment with a $1.000 \mu \mathrm{M} \mathrm{Cd}{ }^{2+}$ solution with bacterial cells. Cells of the recombinant clone BL21/pGEX-EC20, after growth in the condition of induction of EC20 protein expression, showed capacity for removing $37.5 \%$ of the total amount of $\mathrm{Cd}^{2+}$ present in that solution and, even when these cells were grown in the condition of EC20 protein expression repression, they removed $11.5 \%$ of the total amount of $\mathrm{Cd}^{2+}$ (Figure 4). So, induction of EC20 protein expression promotes 26\% increasement in $\mathrm{Cd}^{2+}$ bioaccumulation of the recombinant clone cells (Figure 4).

These are satisfactory results that can be comparable to those previously described with recombinant clones expressing EC20 (BAE et al., 2000), C. metallidurans (BIONDO et al., 2012) and D. radiodurans (CHATURVEDI; ARCHANA, 2014). This indicates that this approach offers a good potential for the construction of new bacterial strains useful for bioremediation of wastewaters containing heavy metals or to recover valuable metals that still remains in those waters.

\section{CONCLUSION}

It was successfully describe the construction and characterization of recombinant $E$. coli clones expressing intracellularly the synthetic phytochelatin EC20. As expected, the recombinant clones, in comparison to untransformed cells, showed an increased biosorption capacities of $\mathrm{Cd}^{2+}$, and this confirms that this approach offers good and new prospects for future applications in bioremediation procedures of water contaminated with heavy metals as cadmium or even for recovery of valuable heavy metals present in water. Moreover, in this research, it was demonstrated that EC20 expression also promotes an increasement on the bacterial resistance to $\mathrm{Cd}^{2+}$. 
RESUMO: Foram construídos clones recombinantes de E. coli que expressam intracelularmente a fitoquelatina sintética EC20. Foi analisado o aumento na capacidade de biossorção de $\mathrm{Cd}^{2+}$ e o aumento da resistência a este metal tóxico. Foi sintetizado in vitro um gene codificante da fitoquelatina sintética EC20. O gene EC2O sintético foi amplificado por PCR, inserido nos vetores de clonagem pBluescript ${ }^{\circledR} \mathrm{KS}^{+}$e $\mathrm{pGEM}^{{ }_{-}}$ TEasy, e nos vetores de expressão pTE [derivado de pET-28(a) ${ }^{\circledR}$ ] e pGEX-T4-2 ${ }^{\circledR}$. Os plasmídeos recombinantes foram empregados na transformação genética de E. coli: pBsKS-EC20 e pGEM-EC20 foram introduzidos nas linhagens DH10B e DH5 $\alpha$; e, pTE-EC20 e pGEX-EC20 na linhagem BL21-DE3. A expressão EC20 foi analisada por SDS-PAGE. As resistências a $\mathrm{Cd}^{2+}$ dos clones recombinantes foram determinadas por análises de MIC. A MIC para $\mathrm{Cd}^{2+}$ de DH10B/pBsKS-EC20 e de DH10B/pGEM-EC20 foi 2,5 mM (EC20 induzido) e $0,312 \mathrm{mM}$ (EC20 reprimido); respectivamente, 16 e 2 vezes superiores às do controle DH10B/pBsKS $(0,156 \mathrm{mM})$. A MIC para $\mathrm{Cd}^{2+}$ de BL21/pTE-EC20 foi 10,0 $\mathrm{mM}$ (EC20 induzido) e 2,5 mM (EC20 reprimido), comparado a do controle BL21/pTE que foi apenas 1,25 mM. A análise de ICP-AES mostrou que BL21/pGEX-EC20, após crescimento na condição de expressão de EC20, absorveu 37,5\% de Cd ${ }^{2+}$ e, mesmo quando cultivado na condição de não-indução de expressão EC20, absorveu $11,5 \%$ de $\mathrm{Cd}^{2+}$. Estes resultados permitem a conclusão de que os clones recombinantes de E. coli que expressam a fitoquelatina sintética EC20 apresentam aumento da capacidade de biossorção de $\mathrm{Cd}^{2+}$ e de resistência a este íon tóxico.

PALAVRAS-CHAVES: Escherichia coli. Fitoquelatina. Biossorção. Biorremediação. Cádmio.

\section{REFERENCES}

AKPOR, O. B.; MUCHIE, M. Review. Remediation of heavy metals in drinking water and wastewater treatment systems: Processes and applications. Int. J. Phys. Sci., v. 5, n. 12, p. 1807-1817, 2010. Available in: http://www.academicjournals.org/journal/IJPS/article-abstract/00E529A31916. Access in: 28 March 2018.

ANDREWS, J. M. Determination of minimum inhibitory concentrations. J. Antimicrob. Chemother., v. 48, Issue suppl. 1, p. 5-16, 2001. Available in: https://doi. org/10.1093/jac/48.suppl_1.5. Access in: 11 February 2018.

AYANGBENRO, A. S.; BABALOLA, O. O. Review: A new strategy for heavy metal polluted environments: A review of microbial biosorbents. Int. J. Environ. Res. Public Health, v. 14, n. 94, p. 1-16, 2017. Available in: https://doi. 10.3390/ijerph14010094. Access in: 10 April 2018.

BAE, W.; CHEN, W.; MULCHANDANI, A.; MEHRA, R. K. Enhanced bioaccumulation of heavy metals by bacterial cells displaying synthetic phytochelatins. Biotechnol. Bioeng., v. 70, n. 5, p. 518-524, 2000.

Available in: https://doi.org/10.1002/1097-0290(20001205)70:5\%3C518::AID-BIT6\%3E3.0.CO;2-5. Access in: 15 January 2018.

BAE, W.; MEHRA, R. K.; MULCHANDANI, A.; CHEN, W. Genetic engineering of Escherichia coli for enhanced uptake and bioaccumulation of mercury. Appl. Environ. Microbiol., v. 67, n. 11, p. 5335-5338, 2001. Available in: https://doi.org/10.1128/AEM.67.11.5335-5338.2001. Access in: 12 March 2018.

BIONDO, R.; DA SILVA F. A.; VICENTE, E. J.; SARKIS, J. E. S; SCHENBERG, A. C. G. Synthetic phytochelatin surface display in Cupriavidus metallidurans $\mathrm{CH} 34$ for enhanced metals bioremediation. Environ. Sci. Technol., v. 46, n. 15, p. 8325-8332, 2012. Available in: https://doi.org/10.1021/es3006207. Access in: 20 January 2018.

CHATURVEDI, R.; ARCHANA, G. Cytosolic expression of synthetic phytochelatin and bacterial metallothionein genes in Deinococcus radiodurans R1 for enhanced tolerance and bioaccumulation of cadmium. Biometals. v. 27, n. 3, p. 471-482, 2014. Available in: https://doi.org/10.1007/s10534-014-9721-z. Access in: 15 March 2018. 
COBBETT, C.; GOLDSBROUGH, P. Phytochelatins and Metallothioneins: Roles in heavy metal detoxification and homeostasis. Annu. Rev. Plant Biol., v. 53, p. 159-182, 2002. Available in: https://doi.org/10.1146/annurev.arplant.53.100301.135154. Access in: 18 February 2018.

GADD, G. M. Biosorption: critical review of scientific rationale, environmental importance and significance for pollution treatment. J. Chem. Technol. Biotechnol., v. 84, p. 13-28, 2009. Available in: https://doi.org/10.1002/jctb.1999. Access in: 27 December 2017.

GAVRILESCU, M. Removal of heavy metals from the environment by biosorption. Eng. Life Sci., v. 4, n. 3 , p. 219-232, 2004. Available in: https://doi.org/10.1002/elsc.200420026. Access in: 22 March 2018.

GAYLARDE, C. C.; BELLINASO, M. L.; MANFIO, G. P. Biorremediação. Biotecnologia, Ciência e Desenvolvimento. v. 34, p. 36-43, 2005. Available in: http://www1.esb.ucp.pt/twt/olimpiadasbio07/MyFiles/MyAutoSiteFiles/FontesInformacao253906202/samorais/ Biorremediacao.pdf. Access in: 14 April 2018.

GIRIPUNJE, M. D.; FULKE, A. B.; MESHRAM, P. U. Remediation techniques for heavy-metals contamination in lakes: A mini-review. Clean-Soil, Air, Water., v. 43, n. 9, p. 1350-1354, 2015. Available in: https://doi.org/10.1002/clen.201400419. Access in: 16 September 2017.

GUPTA, V. K.; NAYAK, A.; AGARWAL, S. Bioadsorbents for remediation of heavy metals: Current status and their future prospects. Environ. Eng. Res. v. 20, n. 1, p. 1-18, 2015. Available in: http://dx.doi.org/10.4491/eer.2015.018. Access in: 21 August 2017.

LADEIRA, A. C. Q.; PANIAGO, E. B.; DUARTE, H. A.; CALDEIRA, C. L. Especiação química e sua importância nos processos de extração mineral e de remediação ambiental. Cadernos Temáticos de Química Nova na Escola, v. 8, p. 18-23, 2014. Available in: http://qnesc.sbq.org.br/online/cadernos/08/05-CTN3.pdf. Access in: 06 May 2017.

LAEMMLI, U. K. Cleavage of structural proteins during the assembly of the head of bacteriophage T4. Nature, v. 227, n. 5259, p. 680-685, 1970. Available in: https://doi.org/10.1038/227680a0. Access in: 09 June 2017.

MEHRA, R. K.; MULCHANDANI, P. Glutathione-mediated transfer of $\mathrm{Cu}(\mathrm{I})$ into phytochelatins. Biochem. J., v. 307, n. Pt3, p. 697-705, 1995. Available in: https://www.ncbi.nlm.nih.gov/pmc/articles/PMC1136707/. Access in: 26 September 2017. https://doi.org/10.1042/bj3070697

PERELO, L. W. Review: In situ and bioremediation of organic pollutants in aquatic sediments. J. Hazard. Mater, v. 177, issues 1-3, p. 81-89, 2010. Available in: https://doi.org/10.1016/j.jhazmat.2009.12.090. Access in: 12 March 2018.

REEDER, R. J.; SCHOONEN, M. A. A.; LANZIROTTI, A. Metal speciation and its role in bioaccessibility and bioavailability. Rev. Mineral. Geochem., v. 64, n. 1, p. 59-113, 2006. Available in:

https://doi.org/10.2138/rmg.2006.64.3. Access in: 15 March 2018.

SAMBROOK, J.; RUSSELL, D. W. Molecular Cloning: A Laboratory Manual. 3th ed. Cold Spring Harbor Press: New York, 2001, vols 1, 2 and 3, 2100 p.

SAUGE-MERLE, S.; CUINÉ, S.; CARRIER, P.; LECOMTE-PRADINES, C.; LUU, D-T., PELTIER, G. Enhanced toxic metal accumulation in engineered bacterial cells expressing Arabidopsis thaliana phytochelatin synthase. Appl. Environ. Microbiol., v. 69, n. 1, p. 490-494, 2003. Available in:

https://dx.doi.org/10.1128\%2FAEM.69.1.490-494.2003. Access in: 14 April 2018.

STILLMAN., M. J. Metallothioneins. Coord. Chem. Rev., v. 144, p. 461-511, 1995. Available in: https://doi.org/10.1002/chin.199613288. Access in: 20 April 2018. 
UEKI, T.; SAKAMOTO, Y.; YAMAGUCHI, N.; MICHIBATA, H. Bioaccumulation of copper ions by E. coli expressing vanabin genes from the vanadium-rich ascidian Ascidia sydneiensis samea. Appl. Environ.

Microbiol., v. 69, n. 11, p. 6442-6446, 2003. Available in: https://dx.doi.org/10.1128\%2FAEM.69.11.64426446.2003. Access in: 10 January 2017.

VOLESKY, B.; HOLAN, Z. R. Review: Biosorption of heavy metals. Biotechnol. Prog., v. 11, n. 3, p. $235-$ 250, 1995. Available in: https://doi.org/10.1021/bp00033a001. Access in: 22 February 2018.

WANG, J.; CHEN, C. Biosorbents for heavy metals removal and their future. Biotechnol. Adv., v. 27, n. 2, p. 195-226, 2009. Available in: https://doi.org/10.1016/j.biotechadv.2008.11.002. Access in: 03 May 2018.

WAWRZYŃSKA, A.; WAWRZYŃSKI, A.; GAGANIDZE, D.; KOPERA, E.; PIATEK, K.; BAL, W.; SIRKO, A. Overexpression of genes involved in phytochelatin biosynthesis in Escherichia coli: effects on growth, cadmium accumulation and thiol level. Acta Biochim. Pol., v. 52, n. 1, p. 109-116, 2005. Availainble in:

https://www.researchgate.net/profile/Agnieszka_Sirko/publication/7908640_Overexpression_of_genes_involve d_in_phytochelatin_biosynthesis_in_Escherichia_coli_Effects_on_growth_cadmium_accumulation_and_thiol_ level/links/09e415100e65955ef8000000.pdf. Access in: 29 March 2018.

https://doi.org/10.18388/abp.2005_3494

YANG, C-E., CHU, I-M., WEI, Y-H., TSAI, S-L. Surface display of synthetic phytochelatins on Saccharomyces cerevisiae for enhanced ethanol production in heavy metal- contaminated substrates,

Bioresour. Technol., 245, p. 1455-1460, 2017. Available in: http://dx.doi.org/10.1016/j.biortech.2017.05.127. Access in: 27 August 2019. 